\title{
Four-phase geothermobarometry on mantle xenoliths from West Greenland: assessment of P/T-formulations and implications for diamond potential
}

\author{
Karina K. Sand ${ }^{1,2}$, Tod Waight ${ }^{3}$, Troels F.D. Nielsen ${ }^{2}$, D. Graham Pearson ${ }^{4}$, Emil \\ Makovicky $^{3}$ and Mark T. Hutchison ${ }^{2}$ \\ ${ }^{1}$ Nano-Science Center, Department of Chemistry, University of Copenhagen, Universitetsparken 5, 2100 \\ Copenhagen Ø, Denmark (karina.sand@gmail.com). \\ ${ }^{2}$ Geological Survey of Denmark and Greenland, Copenhagen, Denmark. \\ ${ }^{3}$ Institute for Geography and Geology, University of Copenhagen, Denmark. \\ ${ }^{4}$ Northern Centre for Isotopic and Elemental Tracing, Department of Earth Sciences, Durham \\ University, UK
}

In recent years the number of diamond finds from kimberlitic rocks (senso lato) (Nielsen and Sand, in press) in West Greenland has increased, resulting in a greater interest for the diamond potential of the region. Commercial size diamonds have so far only been found within $\sim 20 \mathrm{~km}$ of the undeformed Archean craton boundary as defined by crustal exposures and geophysics (Van Gool et al. 2002). Detailed studies of the mantle beneath this region have been lacking. Here we assess the diamond potential of the southern West Greenland lithospheric mantle using geothermobarometry applied to 4-phase mantle peridotitic xenoliths (garnet, olivine, clinopyroxene, orthopyroxene) from $\sim 600 \mathrm{Ma}$ kimberlitic (senso lato) dikes and sills (Secher et al. 2008). The xenolithbearing occurrences (Fig. 1) are located in three different settings relative to the margin of the undeformed North Atlantic Archean Craton. The Kangerlussuaq area is within the Nagssugtoqian Mobile belt, the Sarfartoq area just outside the deformation zone and the Maniitsoq area is entirely within the craton. The aim of this investigation was to estimate the depth of lithosphere, as sampled by mantle xenoliths and hence the diamond potential of West Greenland and to identify any variations in diamond potential between the three sub areas. A complementary study (Wittig et al. 2008), focused on evaluating the age of the lithospheric mantle beneath the region studied here.

In this study, we focus on garnet lherzolites (cpx, opx, ol) as this rock type provides a better evaluation of chemical equilibrium than other mantle rock types present in the kimberlitic host rock such as garnet harzburgites (ol, opx), garnet wehrlites (ol, cpx) or garnet dunites $(\mathrm{ol})$. The more depleted harzburgites and dunites dominate the xenolith assemblage and hence a number of these other rocks have been also studied to allow a crude estimation of mantle stratigraphy (Sand,
2007, Sand et al., in preparation). The results presented here are from garnet lherzolites only. The PT estimates are calculated iteratively using well-known formulations (Table 1) based on major elements. The mineral compositions used to calculate $\mathrm{P}$ and $\mathrm{T}$ are means of replicate analyses ( $\sim 10$ analyses for garnets) from between three to five grains. Minerals were analyzed using a JEOL 8200 electron microprobe at the Institute of Geography and Geology, Copenhagen, Denmark. The acceleration voltage was set to $15 \mathrm{kV}$ and the beam current to $50 \mathrm{nA}$ and a beam diameter of $5 \mu \mathrm{m}$ was used.

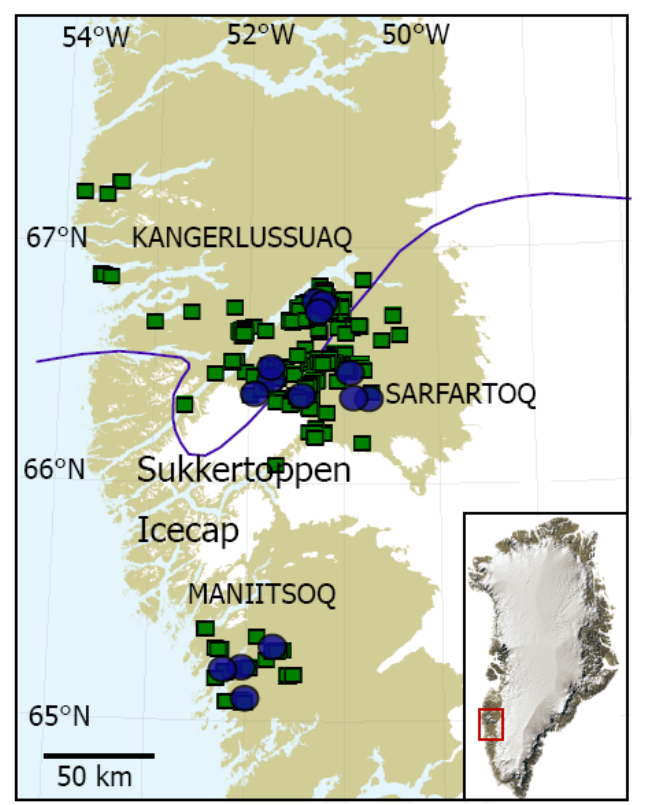

Figure 1: Map of in-situ kimberlitic (senso lato) occurrences (green squares) in the study area. The xenolith-bearing occurrences included in this study are indicated with blue. The blue line represents the boundary to the undeformed Archaean craton to the south. 
The mineral chemistry of the West Greenlandic garnet lherzolites generally resembles that of the Slave and Kaapvaal cratons (Sand, 2007). However, elevated $\mathrm{TiO}_{2}$ contents in clinopyroxenes and garnets are a feature of the West Greenland minerals and further analyses with lower detection limits are required to determine the significance of this feature. For whole rock bulk compositional data the reader is referred to Wittig et al. 2008.

Several geothermobarometers were applied to the data set (Table 1). Consistent results between these formulations based on various mineral and element exchanges are taken as an expression of wellequilibrated samples.

Table 1: PT formulations used for West Greenland peridotites

\begin{tabular}{lcccc}
\hline Method & Minerals & Equilibria & Comments & Accuracy $^{{ }^{2}}$ \\
\hline Barometers & gt-opx & Al exchange & MAS & $\pm 0.6 \mathrm{GPa}$ \\
PMC & gt-opx & Al exchange & SMACCr & $\pm 0.9 \mathrm{GPa}$ \\
PNG & gt-opx & Al exchange & CMAS (SMACCr) & $\pm 0.5 \mathrm{GPa}$ \\
PBKN & $\mathrm{cpx}$ & Cr exchange & SMACCr & $\pm 0.5 \mathrm{GPa}$ \\
PNimis & gt-opx & Fe-Mg exchange & Sensitive to $\mathrm{Fe}^{3+}$ & $92^{\circ} \mathrm{C}$ \\
Thermometers & gt-ol & Fe-Mg exchange & Sensitive to $\mathrm{Fe}^{3+}$ & $180^{\circ} \mathrm{C}$ \\
THarley & opx & Ca exchange & in equilibrium with opx & $60^{\circ} \mathrm{C}$ \\
TO Neill & opx-cpx & Ca-Mg exchange & 4-phase formulation & $60^{\circ} \mathrm{C}$ \\
TCa-in-opx & $\mathrm{cpx}$ & Ca exchange & Equilibrium with gt & $62^{\circ} \mathrm{C}$ \\
TBKN &
\end{tabular}

${ }^{a}$ Accuracies are from the literature and represent a $2 \sigma$ confidence level based on the ability to reproduce experimental data. $\mathrm{Gt}=$ garnet, opx $=$ orthopyroxene, ol=olivine, $\mathrm{cpx}=$ clinopyroxene. $\mathrm{PMC}$ from McGregor (1974), PNG from Nickel and Green (1985), P/TBKN from Brey and Köhler (1990), P/TNimis from Nimis and Taylor (2000), THarley from Harley (1984), TO'Neill from (O'Neill and Wood (1979), and TCa-in-opx from Brey and Köhler (1990).

Despite consistency in temperature estimates using a variety of thermometers, equilibration pressures varied with the choice of barometer (Sand, 2007). In Figure 2 the P/T estimates using PBKN/TBKN are shown with reference to the diamond stability field of (Kennedy and Kennedy, 1976), the model geotherms of (Chapman and Pollack, 1977) and a mantle adiabat (Rudnick and Nyblade, 1999). The general trend of the West Greenland lherzolite data scatters between geotherms of 40 and $42 \mathrm{~mW} / \mathrm{m}^{2}$. Only 3 data points appear to be derived from depths shallower than the diamond stability field. Included in Fig. 2 (blue dots) are equilibrium pressure and temperature conditions calculated for xenoliths from the diamondiferous Garnet Lake main sheet (Hutchison and Frei, this volume), demonstrating that this material is sourced from amongst the greatest depths sampled by West Greenland kimberlitic rocks.

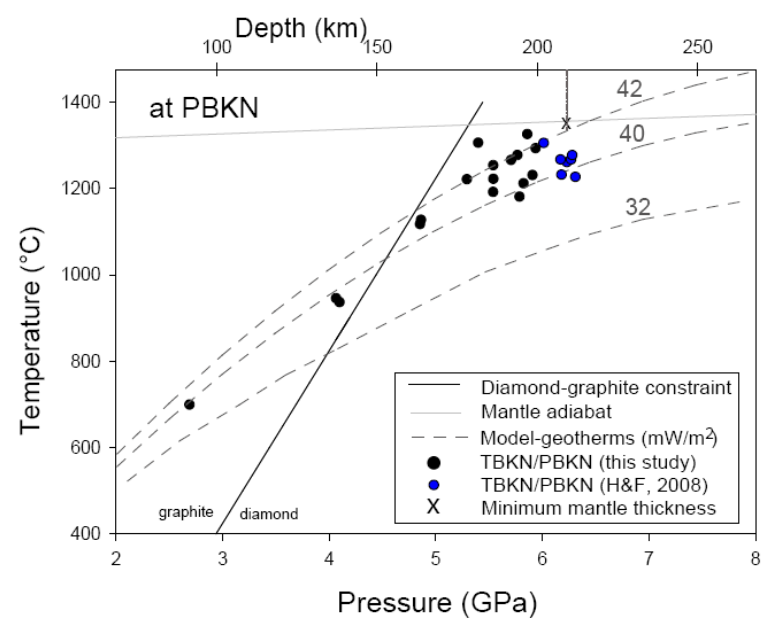

Figure 2: PBKN vs. TBKN. See text for discussion.

The results using the PMC and TCa-in-opx formulations are shown in Figure 3. This apparent geotherm displays a more linear trend that transects the model-geotherms of Pollack and Chapman, (1977) and shows a kink at pressures between 5.1 and $5.7 \mathrm{GPa}$, dividing the xenoliths into a low-T and a high-T suite.

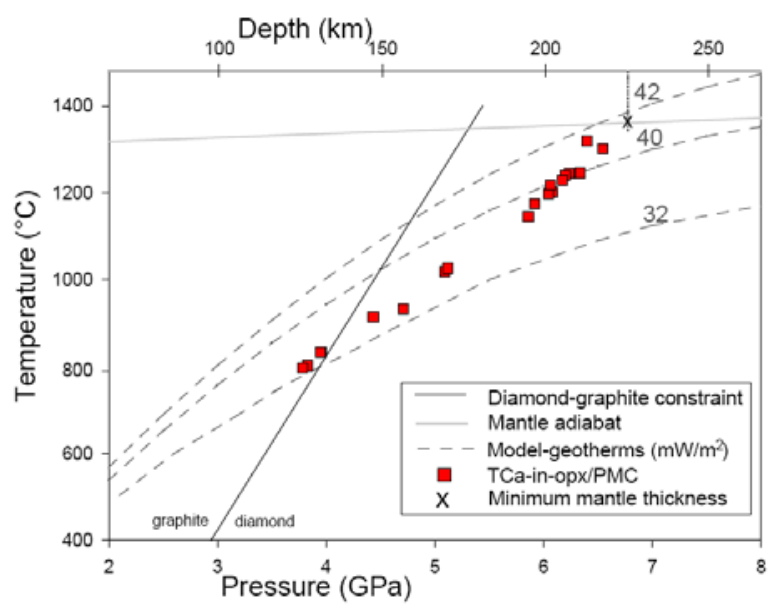

Figure 3: TCa-in-opx vs. PMC. See text for discussion.

Comparing Figure 2 and 3 it is evident that the combination PMC/TCa-in-opx formulation yields greater pressures compared to the PBKN/TBKN formulation. To exclude artifacts of the thermometers, pressure estimates using PMC and PBKN were calculated at a fixed $\mathrm{T}$ (Fig. 4). Here the PMC estimates are consistently $0.5 \pm 0.5(2 \sigma) \mathrm{GPa}$ higher than PBKN. This relative deviation to lower pressures using the PBKN formulation is also observed when compared to the PNG and PNimis barometers. The latter two barometers show, in general, pressures that are consistent with the PMC formulation. These observations are not further discussed here but for these reasons we prefer pressure estimates using the PMC barometer rather than PBKN formulation.

The inconsistency between the barometers and the implication for mantle evolution models are discussed in Sand (2007) and Sand et al. (in preparation). 


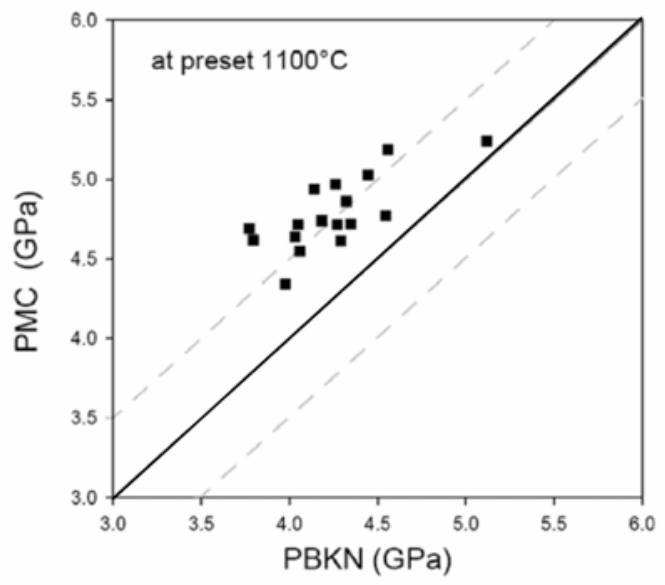

Figure 4: PBKN vs. PMC at $1100{ }^{\circ} \mathrm{C}$. See text for discussion.

The transition from apparent xenolith-based geotherms to the convective heat transfer of the asthenosphere, shown by the mantle adiabat, yields the minimum thickness of the lithospheric mantle (Rudnick and Nyblade, 1999). The base of the lithospheric mantle $\sim 600$ mya ago is here suggested to have been at a minimum of ca. 210-220 km (Fig. 2 and 3). The potentially thicker mantle section and the higher pressures obtained using the PMC formulations yield a greater diamond potential compared to the PBKN formulation. However, most $\mathrm{P} / \mathrm{T}$ estimates from the PBKN/TBKN formulation (Fig. 2) are also within the diamond stability field defined by Kennedy \& Kennedy (1976).

When comparing the $\mathrm{P} / \mathrm{T}$ results between the three regions no lateral variation in $\mathrm{P} / \mathrm{T}$ estimates or heat flows at mantle depths are defined by our data, despite variable crustal histories. We recognize that the spatial coverage of $\mathrm{P} / \mathrm{T}$ estimates from lherzolites is not comprehensive and a more extensive study may be warranted. However, from the available data it is clear that a significant portion of the West Greenland lithosphere was within the "diamond window" at the time of kimberlite eruption 550-600 mya ago, and hence the whole region has considerable diamond potential.

\section{Acknowledgements}

We would like to thanks Berit Wenzel and Hanne Lamberts for technical and practical help and discussions. Hudson Resources Inc. is thanked for provision of Silly Kimberlite samples.

\section{References}

Brey, G. P., Köhler, T., 1990. Geothermobarometry in 4Phase Lherzolites .2. New Thermobarometers, and Practical Assessment of Existing Thermobarometers. Journal of Petrology 31, 13531378.

Chapman, D. S., Pollack, H. N., 1977. Regional Geotherms and Lithospheric Thickness. Geology 5, 265-268.

Harley, S. L., 1984. An experimental study of the partitioning of $\mathrm{Fe}$ and $\mathrm{Mg}$ between garnet and orthopyroxene.
Contribution to mineralogy and petrology $86,359-$ 373.

Hutchison, M.T., Frei, D. 2008. Diamondiferous kimberlite from Garnet Lake, West Greenland II: diamonds and the mantle sample. Extended Abstracts of the 9th International Kimberlite Conference, 9IKC-A00182 .

Kennedy, C. S., Kennedy, G. C., 1976. The equilibrium boundary between graphite and diamond. Journal of Geophysical Research 81, 2467-2470.

McGregor, I. D., 1974. The system MgO-Al2O3-SiO2: Solubility of $\mathrm{Al} 2 \mathrm{O} 3$ in enstatite for spinel and garnet compositions. American mineralogist 59, 110-119.

Nickel, K. G., Green, D. H., 1985b. Empirical geothermobarometry for Garnet Peridotites and Implications for the Nature of the Lithosphere, Kimberlites and Diamonds. Earth and Planetary Science Letters 73, 158-170.

Nielsen, T.F.D. \& Sand, KK (in press): The Majuagaa kimberlite dike, Maniitsoq region, West Greenland: constraint for an Mg-rich silicocarbonatite melt composition from groundmass mineralogy and bulk composition. Canadian Mineralogist.

Nimis, P., Taylor, W. R., 2000. Single clinopyroxene thermobarometry for garnet peridotites. Part I. Calibration and testing of a Cr-in-Cpx barometer and an enstatite-in-Cpx thermometer. Contributions to Mineralogy and Petrology 139, 541-554.

O’Neill, H. S. C., Wood, B. J., 1979. Experimental-Study of Fe-Mg Partitioning between Garnet and Olivine and Its Calibration as a Geothermometer. Contributions to Mineralogy and Petrology 70, 5970.

Pollack, H. N., Chapman, D. S., 1977. Mantle Heat-Flow. Earth and Planetary Science Letters 34, 174-184.

Rudnick, R. L., Nyblade, A. A., 1999. The thickness and heat production of Archean lithosphere: constraints from xenolith thermobarometry and surface heat flow. In: Yingwei Fei, Constance M Berkta, and Mysen., B. Eds.), Mantle Petrology: Field observations and High Pressure Experiments: A Tribute to Francis R (Joe) Boyd. The Geochemical Society.

Sand, K. K., 2007. A geotherm for the cratonic lithospheric mantle in southern West Greenland: thermal implications for diamond potential, Master Thesis, University of Copenhagen.

Sand, K. K., Waight, T., Nielsen, T.F.D., Pearson. D.G., Makovicky, E., Hutchison, M.T. In preparation.

Secher, K., Nielsen, T.F.D., Heaman, L. M., Jensen, S.M., Schjøth, F. 2008 Emplacement patterns of kimberlites and ultramafic lamprophyres in an alkaline province located $64^{\circ}-67^{\circ} \mathrm{N}$ in southern West Green-land - Evidence from 40 new robust age analyses, Extended Abstracts of the 9th International Kimberlite Conference 9IKC A00173.

Van Gool, J.A.M., Connelly, J.N., Marker, M., Mengel, F.C., 2002. The Nagssugtoqidian Orogen of West Greenland: tectonic evolution and regional correlations from a West Greenland perspective. Canadian Journal of Earth Sciences, 39, 665-686

Wittig, N., Pearson, D. G., Webb, M., Ottley, C. J., Sand, K. K., Jensen, S. M. and Nowell, G. M.,2008. Evolution of the mantle root beneath the North Atlantic Craton 9th International Kimberlite Conference Extended Abstract No. 9IKC-A00267. 